\title{
通気による岩盤の冷却効果についで
}

$$
\text { 正会員橋本文 作** }
$$

\section{Study on the Underground Cooling Effect by Ventilation}

\author{
Bunsaku HASHIMOTO
}

By utilizing the periodic (trigonometric) function to the temperature of air current and being as a parameter the lapse of the time since the beginning of ventilation, this paper gives two mathematical solutions about the gallery temperature which is kept constant initially. The one is a temperature distribution in the rock surrounding a gallery, the other is the cooling effect of the rock surface in a downwind direction. The later is an approximate calculation so that there are some errors to be annexed. But it is impossible to estimate its value for there is no complete solution moreover it is unable to observe above effect actually.

Generally speaking author emphasize that the solutions are very simple comparing the public one and are practical for mining engineers to estimate the various cooling effects of the gallery surface by ventilation.

\section{1. 緒 言}

坑道内面の空気温度に週期函数を利用することによつ てまず最初に岩盤内温度分布を与える計算が簡単な解を 誘導した。この種の問題はすで解かれているが汸, 固 有值算出飞非常に面倒な計算を伴う。これは一般の中空 円筒の外面が一定温度に保たれ内面に或る温度の気流が 流れる場合と対比するるのであるが, 岩盤内の温度計算 に当つては一定温度保たれる外面と称するような処が なく温度变化は時間の経過とともに無限の範囲汇拡がる ので, 有限範囲内には温度が一定に保たれるような処は 存在しないことに注意す心゙きである。ここに述へる解法 はかかる境界条件を用いていない。そして計算も今迄の， 解の計算汇較べれば至つて簡単であることを強調した い。

つぎに最初一定温度であつた水平坑道***坑口に和 ける気温が経過時間の 4 倍を基集週期として正弦変化を する場合を仮定し，これの経過時間(1/4週期)に対する坑 道壁面の冷却効果について解析を行なつた。坑口の温度 が一定な空気を流す場合についてはすでに京都大学平

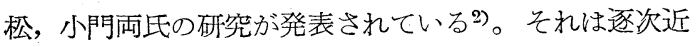
似による数值解法で方針としては間違いないが計算警 くべき時間と計算技術を要し,完全解を出すには無限の,

* 昭和 31 年 7 月 30 日受理 昭和 31 年春季学術講演会で講演

** 早稻田大学第 1 理工学部助手, 鉱山学教室

*** 地熱恬温率が $1^{\circ} \mathrm{C} / 100 \mathrm{~m}$ である立坑, 斜坑の場合も温度の基準 な空気の断熱線にこるならは全く同じである。
ある程度の精度を出すにも相当の日数を要するので実用 的とは云い難い。乙か乙この方法は坑道軸方向の任意の 温度分布に適用乙得る利点はある。これ対して本研究 は上の場合の近似計算とみなされるるのであるが，誤差 は余りないるのと思つている。そして計算は至つて簡単 であり現場で坑道開発に際して通気語けすかたわら各 種坑道断面や風速等の条件のもと飞簡単淿風下方向の冷 却効果を知ることができる。それ的ここに执いては計 算法の根挑を説明し，個々の場合についてはそのうちの 代表的な 2,3 の例を述ふるにとどめる。な技坑口の気温 は現実或る温度を中心拜， 1 日を基準週期とする 週期变化をするが，この場合の冷却，加熱効果はこの解 を応用して知ることができる。

\section{2. 岩盤內の溫度変化}

始めの温度が一様な坑道に一定温度の気流を流す場合 の坑道軸借直断面内の岩盤温度について考光る。熱の

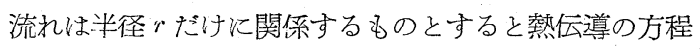
式は

$$
\frac{\partial \theta}{\partial t}=\kappa\left(\frac{\partial^{2} \theta}{\partial r^{2}}+\frac{1}{r} \frac{\partial \theta}{\partial r}\right) .
$$

そなり始めの温度は 0 , 内面 $(r=a) て ゙-1$ の気流に $h$ の強さの輻射がある場合の初期条件, 境界条件はとれぞ れ次のようである。

$$
\begin{gathered}
\theta=0, t=0 \ldots \ldots \ldots \ldots . . \\
\theta^{\prime}-h(\theta+1)=0, r=a
\end{gathered}
$$




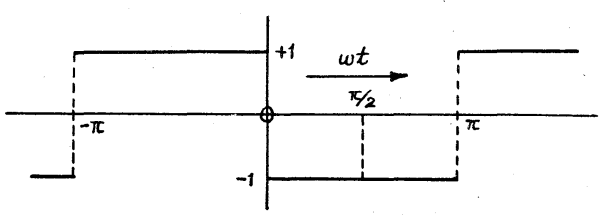

第 1 図

通常（1）は（2），(3) だけでは解けない。もう1つ 温度変化のない距離 bを境界条件として必要々する*。

$$
\theta=0, r=b
$$

$b$ を必要以上に大きくとるときは計算に非常な労力を要 するので許される籁囲内で小さくとることが望ましい。 正確汇は（4）は坑道面から非常に遠くはなれた $(b \rightarrow \infty)$ 岩盤内では温度变化はないというへきである。一般に週 期変化に対しては岩盤内の振幅は急激に小さくなること に注目し，（3）の-1 なる気温を第 1 図のような角速 度がいである週期変化の 1 部であると考学る。すなわち

$$
\left.\begin{array}{rl}
f(\omega t) & =1,-\pi<\omega t<0 \\
& =-1,0<\omega t<\pi
\end{array}\right\}
$$

（5）をFourier 級数に展開すると次のようになる。

$$
f(\omega t)=-\frac{4}{\pi} \sum_{n=1}^{\infty} \frac{\sin (2 n-1) \omega t}{2 n-1}
$$

$\theta=\sum_{n=1}^{\infty} \theta_{n}$ と秝けば $\theta_{n}$ の方程式として

$$
\begin{gathered}
\frac{\partial \theta_{n}}{\partial t}=\kappa\left(\frac{\partial^{2} \theta_{n}}{\partial r^{2}}+\frac{1}{r} \frac{\partial \theta_{n}}{\partial r}\right) \cdots \cdots \cdots \cdots \cdots \cdots( \\
\theta_{n}=0, t=0 \cdots \cdots \cdots \cdots \cdots \cdots \cdots \cdots \cdots \cdots \cdots \cdots \cdots \cdots \cdots \cdots \cdots \cdots \\
\theta^{\prime}{ }_{n}-h\left(\theta_{n}+\frac{4}{\pi} \frac{\sin (2 n-1) \omega t}{2 n-1}\right)=0, r=a
\end{gathered}
$$

$\theta_{n}=0, r=$ great distance

（8），（9)，（10）、を满足する（7）の解は存在しない が. (9)，(10) を满足する (7) の解は次のようになる。

$$
\begin{aligned}
\theta_{n}= & -\frac{4}{(2 n-1) \pi} \\
& \sqrt{\frac{\operatorname{ker}^{2} P_{n^{r}}+\mathrm{kei}^{2} P_{n^{r}}}{R_{n \cdot 1^{2}}+R_{n \cdot 2^{2}}}} \sin \{(2 n-1) \omega t \\
& \left.-\tan ^{-1} \frac{R_{n \cdot 2} \mathrm{ker} P_{n^{r}}-R_{n \cdot 1} \mathrm{kei} P_{n^{r}}}{R_{n \cdot 1} \mathrm{ker} P_{n} r+R_{n \cdot 2} \mathrm{kei} P_{n} r}\right\}
\end{aligned}
$$

ただし

$$
\begin{aligned}
P_{n} & =\sqrt{\frac{(2 n-1) \omega}{\kappa}} \\
R_{n \cdot 1} & =\operatorname{ker} P_{n} a-\frac{P_{n}}{h} \operatorname{ker}^{\prime} P_{n} a \\
R_{n \cdot 2} & =\operatorname{kei} P_{n} a-\frac{P_{n}}{h} \operatorname{kei}^{\prime} P_{n} a
\end{aligned}
$$

* 物理的には $b$ の有限の值は存在しないが解析の便宜上有限の值を 用いる。その結果それに伴う湤差が付随するこきもちろんであ る。

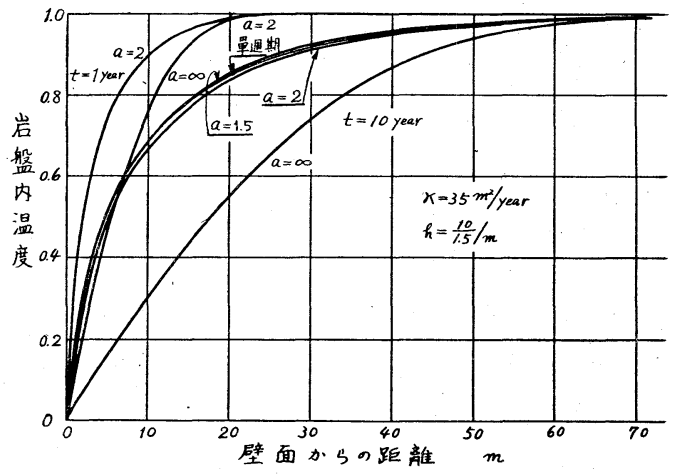

第 2 図

（11）は無限の昔から定常的週期变化のある場合の解で岩 盤内には温度変化の遅れが存在するから（8）を満足さ せるには $0<\omega t \leqq \pi / 2$ の範囲内で近似的に*

$$
\begin{aligned}
\theta_{n} & =-\frac{4}{(2 n-1) \pi} \sqrt{\frac{\operatorname{ker}^{2} P_{n} r+\mathrm{kei}^{2} P_{n} r}{R_{n \cdot 1}{ }^{2}+R_{n \cdot 2}{ }^{2}}} \\
& \cdot \sin (2 n-1) \omega t
\end{aligned}
$$

となる。 $\omega t=\pi / 2$ のときは

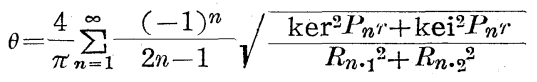

そなりこの場合の䛊差は完全に無視できる。

(12)に和いてある時間後の温度分布を求めるにはその 4 倍の時間を週期とする週期変化を考光ればよい。今 $t=10$, 1year, $\kappa=35 \mathrm{~m}^{2} /$ year, $h=\frac{10}{1.5} / \mathrm{m}, a=1.5,2.0$ $\mathrm{m}, \infty$ の場合の岩盤内温度分布を図示すると第 2 圀のよ うになる。ただし温度はー1を基準としてそこを 0 にと つてある。また (12) を計算するにはある手数を要する ので気温が単週期 ( - sin $\omega t)$ の場合を考学ると (12) と 類似の次式を得る。

$$
\theta=-\sqrt{\frac{\mathrm{ker}^{2} P a+\mathrm{kei}^{2} P a}{R_{1}{ }^{2}+R_{2}{ }^{2}}}
$$

ただし $P, R_{1}, R_{2}$ はそれぞれ (11) の $P_{1}, R_{1 \cdot 1}, R_{1 \cdot 2}$ に対応するものとする。これの $a=2 \mathrm{~m}, t=10$ year, $h=$ $\frac{10}{1.5} / \mathrm{m}$ のときの温度分布は (12) の $a=1.5 \mathrm{~m}$ のとき とほとんどー致する。

以上のことから次の事柄がわかる。すなおち温度分布 は表面付近では大分黑なるが温度变化 0.99 位の処では いずれの場合も一致する（もちろん数值的には異なる）。 そして時間の経過とともに到達距離は増大する。ゆえに 温度変化 0.99 以上のときを考元るときは半無限固体の $h \rightarrow \infty$ の場合の解 $\theta=\operatorname{erf}(x / 2 \sqrt{\kappa t})$. ですべて代用できる ことがわかる。そして $h$ の小は岩盤深部の温度分布に

* $r=a$ の近傍を除けは誤差は瞧視できる。 $r=a$ において $h=5 / \mathrm{m}$ $a=2 \mathrm{~m}, \omega=2 \pi / 4$ year,$\kappa=35 \mathrm{~m} \% /$ year こして誤差は基本週期に 対して $0.032(\omega t=0) \sim 0.0005(\pi / 2)$ であり奇数倍週期に対しては これより小さい。 
は汪とんど影響しない。しかしてbを与完て（2），(3) (4)の条件のもとの（1）の解は複雑な無限級数となるに 反して上の解は（4）の条件を必要とせずしたがつて固 有值計算等の手数が省けて (12) あるいは (13) の計算 は簡単である。

\section{3. 通気による坑道軸方向の冷却効果}

ここに和いては最基本となると思われる最初の温度 が一定な岩盤中に掘られた坑道に通気する場合について 述へたい。筫者は坑口に扔ける気温が単週期変化( - sin $\omega t$ ）であると仮定してこの週期変化による坑内冷却効果 の解析を試みた。上の仮定は坑口における温度が一定の 空気を大気するときの冷却効果楛べれば冷却は革いこ とは明らかであり，坑内を泠却するという目的に対して はある程度（完全解がなく，また実測も不可能であるか らその数值はわからない) の安全率が含まれている。乙 かし坑口付近は別として坑道深部に対しては大した䛊差 はないものと思われる。

\section{$3 \cdot 1$ 解 析}

水平坑道軸方向の任意時間の壁温分布 $f(x)$ に対して 気温 $\chi(x)$ は大気温度を 0 亿換算して次式で示される ${ }^{32}$ 。

$$
\chi(x)=\frac{4 K}{a^{2} u} \sum_{n=1}^{\infty} \int_{0}^{x} f(\mu) e^{-\frac{K \lambda^{2} n}{a^{2} u}(x-\mu)} d \mu
$$

ここに $a$ : 坑道半径, $u$ : 風速, $\lambda_{n}: J_{0}(x)=0$ の $n$ 番 目の正根であり，Kは壁面と気流間の気流の渦拡散率で 坑道断面に関する Reynolds 数 $(\mathrm{Re})$ の函数として

$K=4.40\left(\operatorname{Re} / 10^{5}\right)^{1.41} \mathrm{~cm}^{2} / \mathrm{sec}, \quad \operatorname{Re}=10^{5} \sim 3 \times 10^{6}$ のようにとるものとする*4)。

一般に週期変化（年，日変化）する気温は週期の長い 程坑道深部汉ぶこと抢よびその振幅は指数的に減少す ることは実在の大気坑道について経験的に明らかである から，今最初の壁温が 1 であつた坑道軸方向の壁温分布 が通気によつて冷却されて或る時間後に

$$
f(x)=1-e^{-\gamma x}, \gamma>0
$$

となつたものとする。この仮定の妥当性については後で 触れることにする。しかるとき（14）は

$$
\chi=4 \sum_{n=1}^{\infty}\left(\frac{1-e^{-\frac{K \lambda_{n}{ }^{2}}{a^{2} u} x}}{\lambda_{n^{2}}}-\frac{e^{-\gamma x}-e^{-\frac{K \lambda_{n}{ }^{2}}{a^{2} u} x}}{\lambda_{n}{ }^{2}-\frac{a^{2} v_{1}}{K} \gamma}\right)
$$

となる。坑口から $x$ なる地点において（第3図）

* 岩石裸坑道および支柱坑道の值で，ライニング坑道については流 れの状態が良くなるから $K$ 值は当然上の值こ幾分異なる。

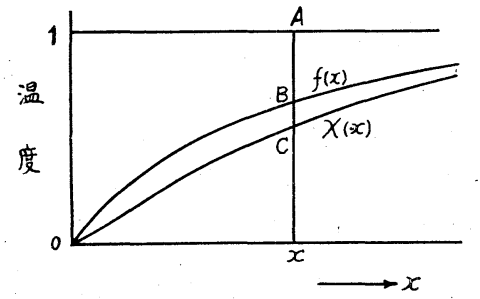

$$
\begin{aligned}
& \frac{\overline{\mathrm{AB}}}{\overline{\mathrm{AC}}}=\frac{1-f(x)}{1-\chi(x)} \\
& 4\left(\sum_{n=1}^{\infty} \frac{e^{-\frac{K \lambda_{n}{ }^{2}}{a^{2} u} x}}{\lambda_{n}^{2}}+e^{-\gamma x} \sum_{n=1}^{\infty} \frac{1}{\lambda_{n}^{2}-a^{2} u^{2} \gamma / K}\right. \\
& \left.-\sum_{n=1}^{\infty} \frac{e^{-\frac{K \lambda n^{2}}{a^{2} u} x}}{\lambda_{n}^{2}-a^{2} u \gamma / K}\right) \\
& \equiv \beta(x) \quad 0<\beta \leqq 1 \\
& \lim _{x \rightarrow \infty} \beta(x)=\lim _{x \rightarrow \infty} \frac{1-f(x)}{1-\chi(x)}=\frac{0.25}{\sum_{n=1}^{\infty} \frac{1}{\lambda_{n}^{2}-a^{2} u \gamma / K}}
\end{aligned}
$$

となる。また一方 $\beta(x)$ は (13) の $-\theta(a)$ に等しく なくてはならない*。すなわち

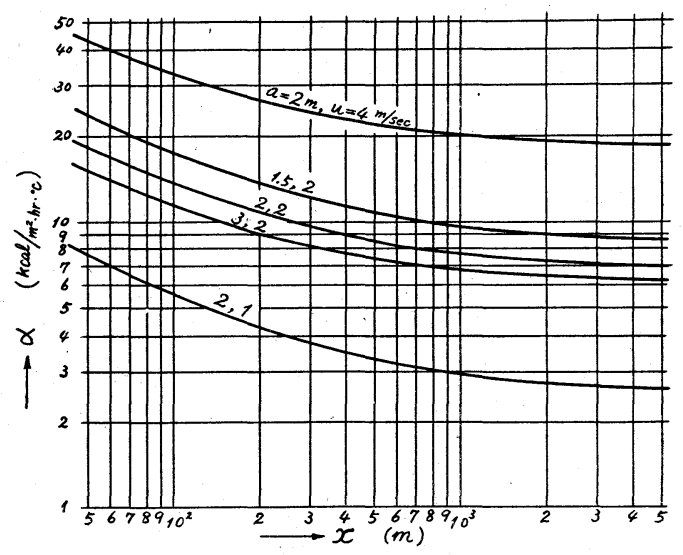

第 4 図

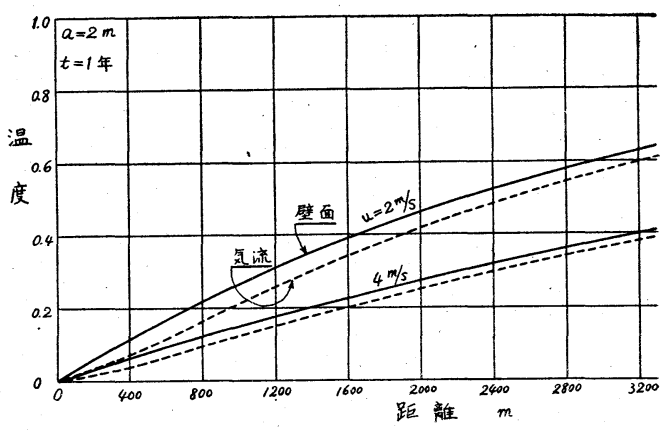

第 5 図 


$$
\beta(x)=\sqrt{\frac{\mathrm{ker}^{2} P a+\mathrm{kei}^{2} P a}{R_{1}^{2}+R_{2}{ }^{2}}}
$$

（19）の右辺恃間, 岩石の熱的性質, 坑道半径抢よび通 気状態によつて決まる壁面と気流閒の局所熱伝達率が関 係している。坑道を一様な岩石中に掘られたるのとする と坑道距離 $x$ によつて変るものは局所熱伝達率 $\alpha$ だけで ある。一般に $\alpha$ は珫口付近では非常に大きく $x$ の増大と ともに急激佀ささくり $\lim _{x \rightarrow \infty} \alpha=\alpha_{\min }$ となることは理論 的住わからているがその数值は坑道のように内壁面が 不規則である大きな管については未知である。そこでこ こでは便宜上 $\alpha$ として坑口から $x$ までの平均熱伝達率で 代用すること炡す。

Stočes-Černik ${ }^{5}$ ) によれば壁温が 1 である坑道に通気 する場合 $\rho ， c_{p}$ をとれぞれ空気の比重量，比熱とすれば 気温义は次式で表わせる。

$$
\chi(x)=1-e^{-\frac{2 \alpha x}{a u p c} p}
$$

また渦拡散の理論にしたがえばる

$$
\chi(x)=4 \sum_{n=1}^{\infty} \frac{1-e^{-\frac{K \lambda_{n}^{2}}{a^{2} u} x}}{\lambda_{n}^{2}}=1-4 \sum_{n=1}^{\infty} \frac{e^{-\frac{K \lambda_{n}^{2}}{a^{2} u^{4}} x}}{\lambda_{n}^{2}}
$$

で表わせるから上の 2 式から次式を得る。

$$
4 \sum_{n=1}^{\infty} \frac{e^{-\frac{K \lambda_{n}^{2}}{a^{2} \omega_{w}} x}}{\lambda_{n}^{2}}=e^{-\frac{2 \alpha x}{\alpha u \rho} p}
$$

ある坑道が指定されれば左辺は既知であるから上式によ つて $\propto$ が計算できる。算出した $\alpha$ は坑口からの平均熱伝 達率と見なされ，局所熱伝達率より幾分大きい值を与兄 ることは明らかである。(20)によつて計算した $\alpha$ の 1 例 を示せば第4困のようである。

これで (19) の右辺が計算できしたがつて (17) の右 辺は值が定まるから $\gamma$ が算出できる。(17)は $\gamma$ 関する 超越方程式であるからこの研究に打いては Newton の 方法によつて根の近似計算を行なつた。訫算結果の 1 例 として $x=1,000 \mathrm{~m} \quad t=1$ year ( $\omega=2 \pi / 4$ year $), \quad a=2 \mathrm{~m}$, $u=2 \mathrm{~m} / \mathrm{sec}, K=46 \mathrm{~cm}^{2} / \mathrm{sec}$ とて $h=7.6 / 1.5 \mathrm{~m}, \beta(1,000)$ $=0.9340, \gamma=3.1 \times 10^{-6} / \mathrm{cm}$ および $u=4, K=124$ とし $\tau h=20.21 .5, \beta(1,000)=0.9744, \gamma=1.6 \times 10^{-6}$ を得 る。この場合の坑道距離 $x$ と壁温, 気温の関係は第 5 図 のようになる。

\begin{tabular}{|c|c|c|c|c|c|c|c|c|c|}
\hline & 離 $x$ & $(\mathrm{~m})$ & 0 & 100 & 200 & 500 & 1,000 & $2,000 \mid$ & $\infty$ \\
\hline \multirow{2}{*}{$\boldsymbol{\beta}$} & $\begin{array}{l}a=2 \mathrm{~m} \\
u=2 \mathrm{~m} / \mathrm{sec}\end{array}$ & $\begin{array}{l}(19) \text { 式 } \\
(17)\end{array}$ & $\begin{array}{l}1.000 \\
1.000\end{array}$ & $\begin{array}{l}0.936 \\
0.979\end{array}$ & $\begin{array}{l}0.953 \\
0.966\end{array}$ & $\begin{array}{l}0.941 \\
0.945\end{array}$ & \begin{tabular}{|l|}
0.934 \\
0.934
\end{tabular} \mid & $\begin{array}{l}0.932 \\
0.931\end{array}$ & $\begin{array}{l}0.930 \\
0.931\end{array}$ \\
\hline & $\begin{array}{l}a=2 \\
u=4\end{array}$ & $\begin{array}{l}\text { (19) } \\
\text { (17) }\end{array}$ & $\begin{array}{l}1.000 \\
1.000\end{array}$ & $\begin{array}{l}0.984 \\
0.990\end{array}$ & $\begin{array}{l}0.980 \\
0.984\end{array}$ & $\begin{array}{l}0.976 \\
0.977\end{array}$ & $\begin{array}{l}0.974 \\
0.974\end{array}$ & $\begin{array}{l}0.973 \\
0.973\end{array}$ & $\begin{array}{l}0.972 \\
0.973\end{array}$ \\
\hline
\end{tabular}

\section{$3 \cdot 2$ 安当性の検討}

前にある時間経過後の壁温が (15) で表わされるもの

\section{第 1 表}

* 気流が坑道を流れる時間はせいぜい $1 \mathrm{hr}$ 以內であつて週期に較 ベれは非常に小さく位相のズレは舆視できる。

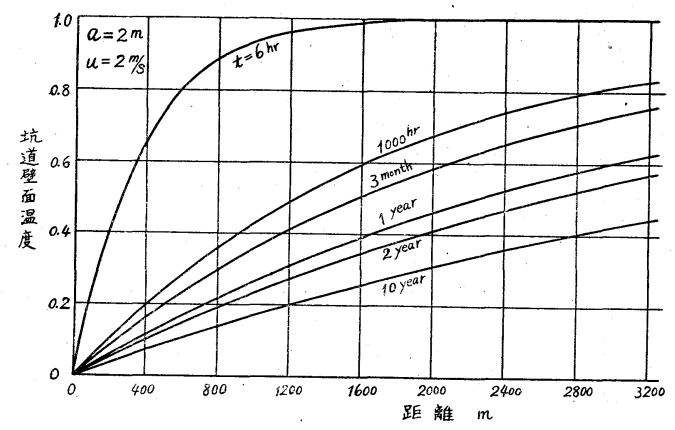

第 6 図

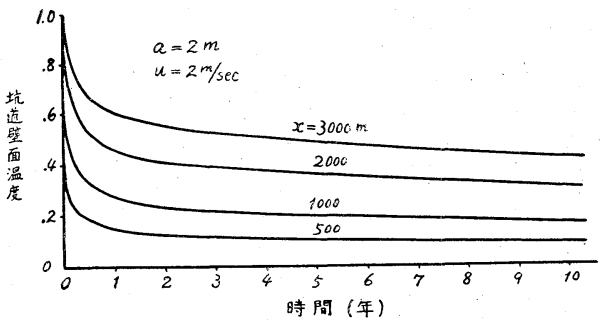

第 7 図

と仮定したが果して（15）あるいはそれに近いるのとな るかどうかの疑問が残る。そこで上の 2 つの場合につい て坑道距離 $x$ の各点に打いて (17) の $\beta(x)$ と (20) か ら出した $\alpha$ を用いて (19) の $\beta(x)$ を計算して比較し て見よう。この両者の值は第1表に示すようである。 $\beta$ の各下段の值は $x=1000 \mathrm{~m}$ に打ける上段の值から (17)

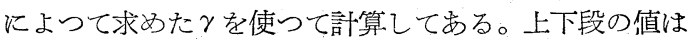
坑口では一致するがそれから両者は少しく喰違い坑道深 部に行くにしたがつて両者はかなりよく一致することが わかる。局所熱伝達率の真值は常に（20）で求めたもの より小さく $x \rightarrow \infty$ で両者は一致すると考完られる。ゆ光 に坑口から浅、距離に物ける各上段の值は真の值より小 さくでていることは明らかであるので上下段の值はより 接近することが期待できる。したがつて対称を一般に実 在する規模程度の坑道にとるならば経過時間のごく短か い間を除いて（15）の仮定は実用上差支它ないるのと思

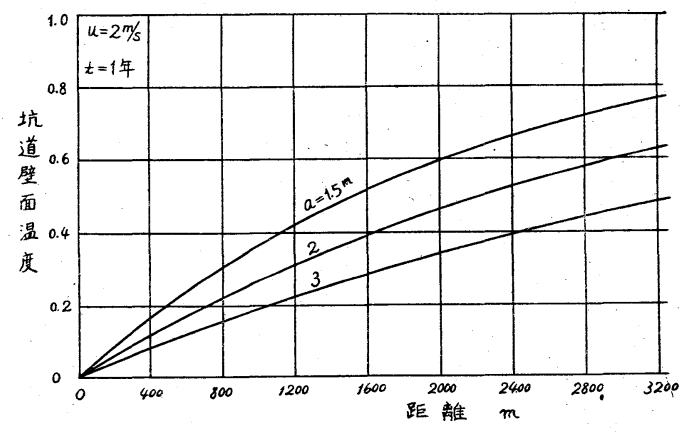

第 8 図 


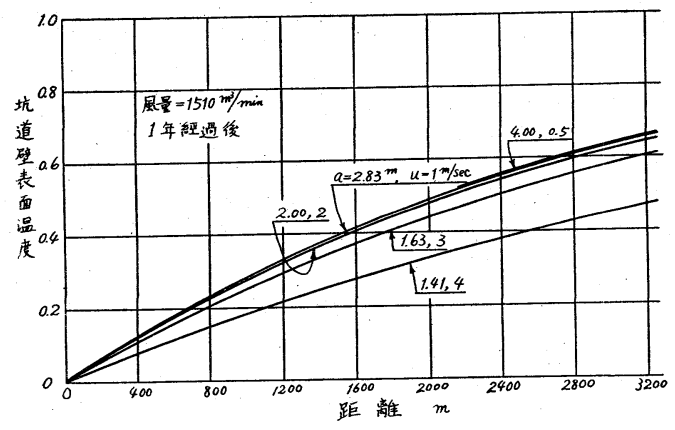

第 9 図

われる。な特 (15) の䛊差は $\beta$ の値が大きい程小さい。 $\beta$ の值は (19) の各項に関係するが一般には気流の規模 が大きく経過時間が長い程大きくなる。

\section{3 冷却効果の 1 例}

2,3 の例について冷却效果を示そう。ただ坑道は最 初単位 1 の温度であつたものとする。

(i) 経過時間による効果 : - $a=2 \mathrm{~m}$ の坑道に $u=$ $2 \mathrm{~m} / \mathrm{sec}$ の空気を流す場合距離と坑道壁面温度の関係は 経過時間をパラメータとして第 6 図のよ5である。この $x=500,1,000,2,000,3,000 \mathrm{~m}$ の各点に特计る坑道壁面 温度と経過時間との関係恃第 7 図のようになる。第 6 困 中 $t=6 \mathrm{hr}, 3 \mathrm{mth}$ の曲線は実在する 1 日, 1 年を基準 週期とする週期変化の $1 / 4$ 週期（夜半扮よび冬季）に相当 し坑口に和ける単位振幅の気温による最低泠却線を示 す。上記 2 曲線の坑道壁面温度 1 の軸化対する対称曲線 を仮想するとこれは上の週期変化の $3 / 4$ 週期（昼和よび夏 季）に相当し坑道壁面の最高加熱温度を示すことにな ·る。云いかえれば現実の週期变化は最低冷却, 最高加熱 曲線の間を絶えず変化しそれ以上に冷却されたり加熱さ れることはない。

(ii) 坑道半径を変える場合 : - $a=1.5,2.0,3.0 \mathrm{~m}$ の坑道に同一風速 $u=2 \mathrm{~m} / \mathrm{sec}$ の気流を通守場合の 1 年 経過後の坑道壁面温度と距離の関係は第 8 困のようであ る。同一風速ならば半径の大きい方が冷却効果は大き w。

（iii）風量を一定とする場合：一一定風量の空気を 流す場合通気開始加ら 1 年後の坑道壁表面温度と距離の 関係は第 9 図に示すようである。たたし風量 $=1,510 \mathrm{~m}^{3}$ $/ \mathrm{min}$ として $u=0.5,1.0,2.0,3.0,4.0 \mathrm{~m} / \mathrm{sec}, a=4.00$, $2.83,2.00,1.63,1.41 \mathrm{~m}$ の各場合についてである。これ について見ると風速が小さいときは冷却効果に大した変 りはないが風速の増大とと炕急激に大きくなる。各種 風量について $\mathrm{a}, \mathrm{u}$ の各場合について調へて見なければ 効果を断言するのは疑問であるが上の例方いて見るな らば冷却効果は断面積を小さくして風速を增した方が大 きい。これは今までの通説と一致する。

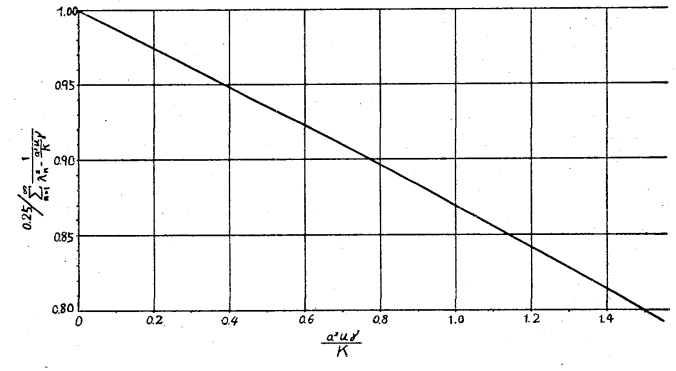

第 10 図

\section{4. 結言}

（i）坑道壁面が最初から温度一定の空気にさらされ ることは稀ではあるが，その場合の岩盤内温度の解を計 算が簡単になるように導いた。この解では面倒な固有值 計算を要しない。また表面の気温が種々に与兄られる場 合の問題を解くときに便宜上必要となる温度变化の及ぶ 範囲を経過時閒をパラメータとして決定できることを示 した6)。

（ii） 通気による岩盤表面温度の冷却効果については 比較的簡単に計算できることを示した。3の計算はある 坑道距離 $(1,000 \mathrm{~m})$ に和ける平均熱伝達率を用いて (17)

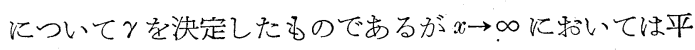
均熱伝達率と局所熱伝達率は一致ずると考穴られるか

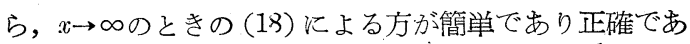
る。そして $a^{2} u \gamma / K$ 各值て対する $0.25 / \sum_{n=1}^{\infty} \frac{1}{\lambda_{n}{ }^{2}-a^{2} u \gamma / K}$ の值を予め計算して第10困のような図表にして稀けばさ らに簡単である。かかる際は 1 つの坑道の特定の経過時 間に対する冷却効果の $\gamma$ を知るに時間にして30分を要し ない。したがつて必要に応じてその都度計算すれば足り るからこの報告では種々に $a, u, t$ を変化する場合につ いては触れていないが一般的に次のことが云える。

a 第6,7 四のよ5に冷却速度は初めは非常に大きい が経過時間ととるに遅くなる。

b （19）からわかるよ5に泠却効果は熱伝達率の大き い方が大きい。

c ，岩石の熱伝達率は（19）の分母，分子に関係して いるのでこれの大小が如何に冷却効果に影響するかは一 概には云えないが* 実在程度の大きさの坑道については 蓺伝導率の小さい方が泠却効果は大きい。この場合は表 面近傍だけが急激に冷却されて周囲の岩盤は徐々に冷却 される。したがつて気流と壁面間の熱の受授量は少なく 気流の温度変化は小さい。

坑道に通気して深部の壁温, 気温が如何になるかを予 測することは作業能率関係するので是非必要であるが

* 通常熱伝導率 $(k)$ の小さい物質は此熟 $(c)$ も小さくしたがつて 温度拡散率 $(k / c \rho)$ は $k$ の小によって余り变化しない。 
完全解が存在しないからその效果を正確滛知ることはで きない。したがつて冷却効果の各計算法ともとの詥差は 測り得ずその精度は比較すへくもないが，計算の難易の 点から見ればここに述心た方法は極めて簡単であり，且 つ経過時閒のごく短い間を除けぼ相当の精度を有するも の々思われる。諸賢の御批判を乞う次第である。

本研究遂行に当り有益な御助言を賜つた本学房村助教 授汇深謝する次第である。
参考交 献

1）例えは天野勳三: 鉱業会誌, 68卷, 774号, 昭和 27 年 12 月

2) 本松・小門: 鉱業会誌, 71 卷, 803 号, 昭和 30 年 5 月; 71 怣 810 号, 昭和 30 年12月

3）橋本交作：早大理工学研究所報告, 第 2 輯, 1955.

4）橋本交作：鉱業会誌，72卷，817号，昭和 31 年 7 月

5) Stoćes-Ćernik : Bekämpfung hoher Grubentemperaturen, $s 9$.

6）例えは次を参照されれい。

交献 2),803号。

橋本交作：鉱業会誌，71怣，809号，昭和30年11月

\section{Book Reviem}

\section{Vol. 7 No. 11}

・石炭中のゲルマニウムに関する研 究 $(8)$ : 稲垣勝他 2 名

\section{地犋学 雜誌 \\ 63 卷 736 号}

・島根県岡見深成岩体中の塩基性包 有岩之花崗岩質 “偽捕獲岩” の成因

（濡木輝一）・・澎湖玄武岩（滄顔 波）

\section{地椞調查所月報 \\ 7 卷 10 号}

- 関東南部の地層の大区分について （伊田一善他 2 名） - 北海道幸内 鉱山和よび大潼鉱山褐鉄鉙鉣床調査 報告（吝藤正雄・五十嵐昭明）・岡 山県南部地域ならびル鳥取県中部地 域空中放射能探査報告（佐藤光之助 他 2 名)

\section{7 劣 9 号}

・工業用調查グループ（徳島県吉） ・野川秎よび那賀川水系工業用水源 地域調查報告 - 石狩平野篠津泥炭 地の地表下堆積状態の泥炭地地下水 の水質 (尾原信彥)

\section{分 析 化 学 6 卷 1 号}

・鈗石中のウランの定量（鞍馬寿雄 他 4 名）・容量法淿よるバォジウム の迅速定量法・フッ硝酸酸洗液中 の遊離酸, 鉄, クロム, フッ化水素
酸の迅速作業分析法の研究（向江脇 公雄）・ベリジウムの分析化学的 研究 (18報) 佐賀県杉山産緑杜石よ りベリリウムの抽出招よび分離（秋 山知行)

\section{ウ ー ゴリ 19566 号}

・石炭鉱業に招けるアイソトープ利 用の問題 (続) : ヴェ・エフ・スミ ルノーフ・石炭鉱業に特讨る放射 線の利用笑験について：ヴェ・ゲイ ・セガリイン・石炭鈗業の建設と 計画とに和ける“無䭾”をなくせよ : カ・カ・クズネッーオフ ・充填 による水平分層採炭方式を採用乙自 然発火に対する危険性を減少した例 :ア・ペイ・クウリコーフ・粉栕 の測定用カメラ ИГЛ : ヴェ・エス・ ニキーチン・石炭ズリの水力輸送 :ヴェ・ヴェ・トライニング・近 い将来の炭坑問題に関する論争 : ア ・エム・バアグゼイン・未来の炭 坑の電化経㗬について：エム・ア・ ゴルイデイン・近い将来の炭坑： ゲ・イ・トーカレエフ・合理的な 発破孔長 : ベー・ゼー・イズラェリ 一下・平層採炭切羽に招ける総合 機械化の主要方向について：アー・ ヴェー・トプチェフ他 2 名・採炭 準備坑道の掘進機械化：デー・ベー ・ルヤビン他3名・ガス突出の危 険度の高い採炭坑道を掘進する場合 の大口径先進ガス拔孔の有効性につ いて：エス・エム・ガルカヴィ ・ク ズバスに知けるコンバイン の操業:ア・エヌ・ヴオルコフ

\section{ERZMETALL}

Nov. 1956

- Über den Einfluß von Zinkoxyd und Zinksulfid in flüssigen Schlacken : Friedrich Johnnsen und Klaus Holler - Neuartige Förderbänder im Erzbergbau: Hans Fritzsche - Eine neue photometrische Thallium-Bestimmu ng in Blei, Zink und Kadmium : Heinz Pohl - Verschleißerscheinungen in Flotationszellen der Aufbereitung Rammelsberg : Martin Clement

Dez. 1956

- Die Messung der Belüftung von Flotationszellen : W. Siemes: und J. F. Kauffmann - Beiträge zur Metallgewinnung durch Druckreduktion: O. Knacke, F. Powlek und E. Süßmuth • Metasomatische Blei-Zink-Erze in Nordspanien : Hellmut Grabert - Spülversatz aus Flotationsabgängen im Tiefbau der Grube Maubacher Bleiberg : Otto Arnold - Weitere Erfahrungen mit. Xanthaten höherer Alkohole : Günther Erberich

\section{SCHLÄGEL und EISEN}

Dec. 1956

- Grubenlokomotiven für Fahrleitungs, Batterie-Verbund-und Kabeltrommel-Betrieb : Otto Türstig - Die Flotation im nordfranzösischen Kohlenrevier : L. Beauxis und R. Veillet

$$
\text { そ の 他 }
$$

○金属 27卷 2 号

-ウランの貧鉱好理（鈴木簀）

Book Reuieca 